\title{
The Untold Story: The Regulation of Police Labour Rights and the Quest for Police Democratisation
}

\author{
Monique Marks \& Jenny Fleming
}

This paper explores the struggles for labour and social rights on the part of police officers in democratising countries. The paper suggests that the rights of police officers and labourmanagement relations are important issues to be acknowledged if we are serious about deepening the democratic practices of police, particularly in democratising countries. These issues should be deliberated among policing scholars and police managers as well as important international regulatory organisations such as the ILO whose current regulatory frameworks inadvertently restrict police worker rights.

Keywords: Police; Police Unions; Democratic Policing; International Labour Organisation; Argentina; Southern Africa

\section{Introduction}

Absent from current policing debates is the issue of police labour relations and the rights of police officers. There is an untold story taking place within police organisations in certain parts of the world. This untold story concerns ongoing struggles of police officers

\footnotetext{
Monique Marks is a member of the Sociology Program at the University of KwaZulu-Natal. She is also a Visiting Fellow at the Regulatory Institutions Network (RegNet) at the Australian National University. Her most recent book is Transforming the Robocops: Changing the Police in South Africa (2005, University of Natal Press). Jenny Fleming is Professor of Police Studies at the Tasmanian Institute of Law Enforcement Studies at the University of Tasmania and a Visiting Fellow at Security 21, Australian National University. She is the editor (with Jennifer Wood) of Fighting Crime Together: The Challenges of Policing and Security Networks, (2006, UNSW Press). She has published widely in the field of police studies. Jenny Fleming wishes to acknowledge the support of the Australian Research Council Grant No: LP0346987. Correspondence to: Monique Marks, Sociology Programme, University of KwaZulu-Natal, Durban 4041, South Africa. Email: monique.marks@anu.edu.au
} 
in emerging democratic regions of the world to attain workplace rights, in particular the right to freedom of association and the right to collectively bargain. How these demands will be configured will depend on national, regional, and international regulatory influences as well as the regional and international initiatives of police employee organisations.

The struggles for rights on the part of police officers in democratising countries should not be viewed separately from quests to democratise public police agencies in these countries. We argue in this paper that management-labour relations and the rights of police shape the internal subjectivities of police in important ways. These internal subjectivities have consequences for broad democratisation projects (often internationally defined) in police organisations. The basic assumptions and values that police members have about democratic rights and freedoms are shaped by their own personal and organisational experience of these rights. While the policing literature has concerned itself with the governance and democratisation of policing, policing scholars have failed to recognise the interconnectedness of these matters to the rights of police officers. In this paper, we present (an undoubtedly controversial) view that police members at all levels are more likely to respond toward the public in democratic and fair ways if they themselves experience the benefits of such behaviour in their own organisational lives.

Deep level cultural change, particularly in respect to the furtherance of democratic values and dispositions, is unlikely to occur via reform programmes that focus on structural organisational change, legislative change, and training programmes. As Otwin Marenin has recently commented, 'the conversion of emergent international values into locally effective and legitimate policing systems has proven complex and difficult' (2004, p. 108). In thinking about and effecting deeper level cultural change within police organisations, greater recognition needs to be given to the fact that police themselves are change agents and that they have 'extraordinary experience, resources and knowledge' (Marx, 2000, p. 2) to either block or encourage social change. This needs to be acknowledged by policing scholars, important regulatory bodies, and police managers, all of whom may need to rethink their current schemas on the relationship between democratic policing and the rights of police workers. The International Labour Organisation (ILO) in particular, as an important international (human rights) regulatory body, should reconsider its current conventions which have been utilised to limit the social and labour rights of police employees.

The paper is in five parts. The first section looks at police rights in democratising countries and the relevance of Janet Chan's conception of police cultural change to policing and human rights. The second section examines attempts by Argentinean police to develop an independent police union. The third section considers the role of the ILO in the regulation of labour and its specific role in the Argentina case. Police employee organisation in South Africa and the Southern African region is examined in section four and the liberalisation of police labour rights globally is the focus of section five. The conclusion supports the growth of police unionism in democratising countries as a supportive and positive influence on democracy generally and democratisation of policing more specifically. 


\section{Police Rights in Democratising Countries}

When countries begin to democratise, new discourses emerge linking policing and democratic rights. Debates and policies about the new 'reformed' role of the public police refer directly to the need for police to become more human-rights-oriented in their philosophy and in their practice. There is rarely mention of police rights and how these could be associated with rights-oriented policing. Instead, much of the rights discourse and related practice models in democratising counties is 'imported' from Western democracies where community policing and human-rights-oriented policing are embedded in police dialogue and policy (Brogden, 1999). Little thought is given to how a new 'rights' culture can be developed in police agencies in these newly democratised countries.

There are two questions that need to be asked about ways in which new rights discourses and practices are inculcated in public police organisations. What mechanisms are used to shift public police agencies in democratising countries from authoritarian practices and philosophies to those which are rights respecting? How is it possible to fundamentally change the culture of the police so that police come to view themselves as social agents who have an important role in promoting and protecting democratic rights and freedoms?

Recently, this has been attempted through new training programmes that have a strong human rights and community policing component (Marenin, 2004). International policing advisors have introduced new models and institutional arrangements with the aim of 'translating the core principles associated with community policing ... into institutional practice' (van Zyl Smit \& van der Spuy, 2004, p. 4). Changes may have resulted from these reform mechanisms but they are limited, having altered 'rhetoric rather than the reality of operational policing' (Dixon, cited in van Zyl Smit \& van der Spuy, 2004, p. 7). We suggest that the deficits in police reform toward human rights and community-oriented policing is in part due to poor conceptualisations and programmes for changing deep level police culture.

But how is it possible to hasten police cultural change so that police come to consistently view their role, the communities they serve, and themselves through rights-based lenses? Chan $(1996,1997)$ makes the important point that police are themselves agents of change, not 'passive recipients of acculturation' (cited in Wood, 2004, p. 35). Borrowing from the work of Edgar Schein, Chan suggests that police negotiate their structural world according to 'systems of dispositions' or 'habitus' (2001, p. 119) which itself is shaped through the transmission of 'cultural knowledge.' This cultural knowledge 'contains basic assumptions about descriptions, operations, perceptions and explanations about the social and physical world' (Chan, 1999, p. 105). In order for police organisational change to occur, 'deep level' cultural change needs to be effected. Chan also reminds us that 'members of a group operate in a particular social and political context that consists of certain structural arrangements of power, interest and authority' (1999, p. 105) — the 'field' of policing. Changes in cultural knowledge therefore need to be supported by changes in the field if real behavioural change and changes in self-perception and perceptions of police work are to take place. 


\section{M. Marks \& J. Fleming}

What relevance does Chan's conception of police cultural change have for policing and human rights? For police cultural knowledge about rights to be reinforced and transformed, new training programmes and the institutionalisation of new policies is not sufficient. Rather, police themselves should be able to directly experience the benefits of newly awarded citizen rights in order for shifts in cultural knowledge to occur. It is through such experiences that police are most likely to rethink and reformulate their own dispositions in regard to citizen rights, particularly the rights to freedom of association and freedom of expression. Having realised the benefits of such rights in their own organisational and personal work experience, they are likely to recognise and respect the integrity of such rights in the environment external to the police organisation. However, there is a greater chance of police cultural change if the mechanisms for change touch the everyday organisational experiences and deeper level assumptions and values of police officers than that which could be achieved through more conventional mechanisms of training and policy initiatives.

It must be said, however, that police employee representative organisations are not inherently democratic, nor do their members necessarily transmit the rights they have secured onto external non-police groupings. As many policing scholars have pointed out, they are often conservative organisations (Cox, 1996; Reiner, 1978). They have tended to oppose police withdrawal of labour, resisted affiliation to broader trade union federations, and have protested against oversight bodies, further training, and police civilianisation programmes (Gammage \& Sachs, 1972; Juris \& Feuille, 1973). However, as this paper will demonstrate, and in particular in reference to South Africa, police employee representative organisations can provide an opportunity for police officers to reorient their strongly held assumptions and values and hasten reform processes aimed at more rights-based policing practices. The following section examines attempts by Argentinean police to form an independent police union and demonstrates how the ILO, through its Conventions and determinations, has (perhaps inadvertently) endorsed the denial of social and labour rights to police employees as decreed by national governments in previously authoritarian states.

\section{The Mobilisation and Regulation of Police Employees in Argentina}

In late 2003, two organised groupings of police members in Buenos Aires (Argentina) approached the International Labour Organisation Body on Freedom of Association to review a decision by the Argentina government denying police members the right to unionise. The case emerged following attempts by low-ranking Buenos Aires' police officers to form and register a police union. The proposed union, according to union public statements, would address the poor working conditions of Argentinean police officers and curb the despotic nature of labour relations generally. It was argued by leaders of the police union that the union would 'not only improve police working conditions, but would also help rein in the "police mafia" and "trigger happy" officers who are responsible for hundreds of deaths each year' (Latinamericapress.org, http:// www.communitiesbychoice.org/printme.cfm? ID=1226\&print=1). The Buenos Aires 
police hierarchy responded by opposing unionisation and expelling 'agitators' from the police force. Similar responses occurred in other provinces of Argentina. For example, the right to unionise in the Sante Fe province was denied on the grounds that 'police forces are recognised vertical structures which are essential for maintaining discipline, while the key characteristic of trade unions is the horizontal relations among their members' (Obeid \& Weisenberg, 2003, p. 11). Police authorities argued that police union activities would undermine disciplinary procedures. The Government also argued that 'the armed forces and the police are not independent of the State, but represent it and are part of it, since they are the sole repositories of public authority and guarantors of internal security' (cited in ILO, 2003a, p. 5).

In making its case for the prohibition of police unions, the Government of Argentina deferred to the ILO's core labour conventions and argued that its decision was in accordance with ILO Convention No. 87 which deals with freedom of association and Article 9 of Convention No. 87 (on Freedom of Association and the Right to Organise) which provides that 'the extent to which the guarantees provided for in this Convention shall apply to the armed forces and the police shall be determined by national laws or regulations' (Shizue Tomoda, ILO Public Services Specialist, email correspondence, 20 January 2004). The Argentina government cited this and Article 8 of the International Covenant on Economic, Social and Cultural Rights that stipulates that while guaranteeing the freedom to form a trade union, permits restrictions in the interests of national security or public order. The government concluded that the restrictions imposed in 'no way constitutes a violation whatsoever of the letter and spirit of Convention No. 87' (cited in ILO, 2003a, p. 5).

The case was referred by the police union to the ILO Committee on Freedom of Association. This ILO committee concluded its deliberations in favour of the Argentina government restating that the guarantees provided in the ILO Conventions on freedom of association apply to the police and the armed forces and shall be determined by national laws or regulations (ILO, 2003a). And so, the story ends with the rights and freedoms of police members in Argentina curtailed by a nation state and an international regulatory organisation committed to the promotion of social and labour rights.

What does this story tell us? What can be gleaned about regulatory bodies as regards the social and labour rights of the police? What can we learn about the characterisations of police organisations? What are the potential consequences of such characterisations for the police and for the democratisation of policing? Let us look more closely at the Argentina government's argument in defence of the prohibition of police trade union rights. The main argument against police unionisation is that the public police are a quasi-military organisation that operates on a command and control basis. The government argues that the democratic ethos and practices of trade unions is at odds with hierarchical, command-oriented police customs. The police are as a result characterised as state agents with no rights to independent action or identity. Characterising the police as state agents and part of a militarised institution contradicts international attempts to civilianise and demilitarise policing organisations (Bayley, 1994; Boda, 2003; Goldstein, 1990; Independent Commission on Policing for Northern Ireland, 1999; Shaw, 2002). The notion that police organisations should not value democratic 
traditions internally and that police officers' rights should be limited to allow for effective (unquestioning) response to the commands of superiors, contradicts conceptualisations of democratic community-oriented policing which stress police adaptability, problem solving, and innovation. In democratising countries, if the citizenry is to confer legitimacy on police, they need to have some organisational independence from the government and clear distinctions need to be made between the functions of the police and the military.

The Argentinean government, in asserting their own regulatory framework made use of international conventions and labour standards as a form of 'blame diversion' (Braithwaite \& Drahos, 2000). But, in reality, how important and effective is the ILO as a regulatory institution? The ILO is a key international player in the regulation of labour rights. Its stated goal is 'to contribute to the establishment of universal peace through promoting social justice by improving working conditions and labour rights throughout the world.' There are currently 177 independent nations represented at the ILO but the ILO is open to all countries that are members of the United Nations. The international labour standards established by the ILO are 'the global model for workplace rights and responsibilities' (ILO, http://www.ilo.org/public/english/standards/ norms/howused/index.htm).

The ILO has significant influence in regards to facilitating normative orders and practices for workplaces in the private and public sector. As economic, political, social, and cultural relations across borders have intensified, the ILO has become increasingly important in developing and regulating core labour standards throughout the world (Biffl \& Isaac, 2002; Elliot, 2000). However, there are vast differences in the capacity and willingness of developed and developing countries to apply these core labour standards. Developing countries for example often lack the institutional arrangements to do this and to develop safety nets and social insurance (Biffl \& Isaac, 2002). Yet we should not overstate the regulatory capacity of the ILO. The ILO is not an independent entity. It is the collective sum of its member states, and inherent within this body are all the shortcomings and inefficiencies found in the member states-many of which are opposed to police unionisation. Shizue Tomoda of the ILO Secretariat points out the limitations of the ILO in this regard:

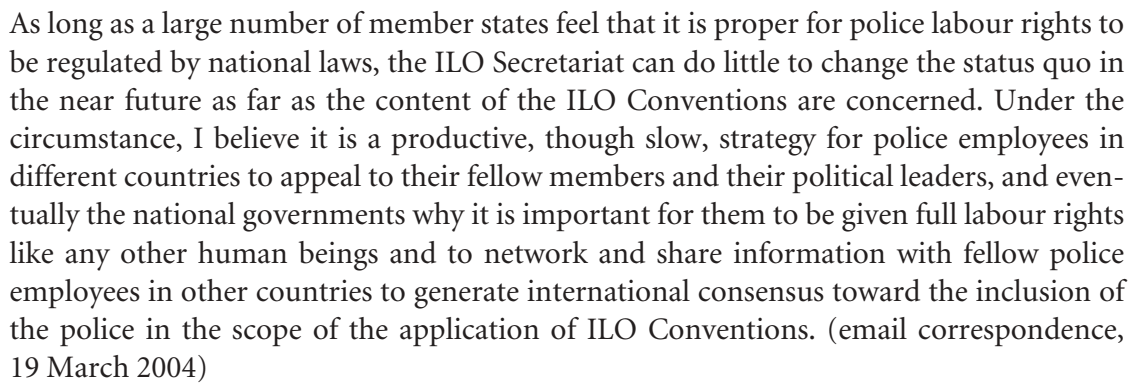

We will return to these limitations later in the paper. In the following section we turn to the case of the Southern African region and show how police employees in this region are pursuing the right to unionise. In this region, the ILO is playing a facilitative 
role in regard to the enhancement of police labour through organising technical workshops for police, focusing on labour law reform and collective bargaining skills (email correspondence with Jane Hodges, ILO labour law specialist, 28 January 2004). But, what is perhaps more important is that in Southern Africa, quite aside from the current ILO Conventions, models and ideals about police labour rights are being diffused from one country to the next.

\section{The Mobilisation for Police Labour Rights in Southern Africa}

Since 2001 there have been regional initiatives in Southern Africa geared toward the liberalisation of labour-management relations within public police organisations. This has occurred in a context in which the rights of police officers are constrained given the continued authoritarian rule in the Southern African region (despite government promises of greater democratisation). The quest for increased labour rights for the police in Southern Africa was inspired by these rights being awarded to the police in South Africa following the transition to democratic governance. Police labour relations in South Africa were formally liberalised with the promulgation of the first South African Police Labour Regulations in November 1993, some time after the first police union, the Police and Prison Civil Rights Union (POPCRU), was launched.

POPCRU was launched in 1989 at the height of the anti-apartheid defiance campaign. At the time of its (defiant) launch, many of the leaders of POPCRU were suspended from the police force, others were arrested. POPCRU was at the time of its inception (and to a large extent still is) a union that predominantly represented black police officers. POPCRU had strong alliances with the progressive trade union movement, the Congress of South African Trade Unions, and with the liberation movement. In many ways POPCRU's self-identity (as its name suggests) is both a civil rights organisation and an industrial union. This identity characterised most other trade unions affiliated to the liberation movement in the 1980s, leading some to refer to trade unionism in South Africa as social movement unionism (Webster, 1988).

At present in South Africa there are two police unions-POPCRU and the South African Police Union (SAPU). Through the new South African Labour Relations Act (1995), police employees have been awarded the same rights as any other worker in South Africa (aside from the right to strike) and police managers and employee organisations are obliged to engage in social dialogue and to collectively bargain. POPCRU and SAPU collectively bargain in a separate bargaining chamber in the Public Service Co-ordinating Bargaining Chamber. The police bargaining chamber has become a forum for dealing with (i) issues pertaining to conditions of service, (ii) broader transformation issues such as health and safety, affirmative action, (iii) police policy matters such as national crime prevention strategies and police plans (Marks, 2000a; Mgijima, 2003). Over the past decade, the police unions in South Africa have played an important role not only in determining officers' salaries and fringe benefits, but also in shaping policies on promotions, assignments, discipline, and other conditions of work. As well, the police unions in South Africa, particularly POPCRU, are concerned about the external democratisation of the police force. They have initiated campaigns centred on 
building police professionalism and were one of the first advocates of community policing in South Africa. POPCRU was the first collective police body to take a stand against repressive and discriminatory policing in South Africa (Brogden \& Shearing, 1993 ) and they continue to campaign for affirmative action processes and equity within the police and also for equitable police resource allocation to rich and poor communities (Marks, 2000a, 2000b).

South Africa remains an exception with regard to police labour relations in the Southern African region. Police in the rest of the Southern African region are prohibited from joining representative organisations and are excluded from existing labour relations legislation. Rank-and-file police members have no forums or processes to participate in workplace or broader policy and planning. Police do not have the right to collectively bargain and grievances are dealt with through an autocratic ranking system. While police associations do exist in many Southern African countries, these associations do not have the right to negotiate on issues of wages and working conditions. Their key functions are the provision of benefits to police members such as providing assistance to families of police officers who have died on duty.

In recent years, expressions of discontent among police members in the Southern African region have begun to surface. This discontent was evident at an international conference on police labour relations, held in Durban in October 2002 and hosted by the University of Natal, POPCRU, and the ILO. The ILO, through its generous funding of the conference, indicated its support for discussions and processes aimed at improving police labour-management relations and the promotion of social dialogue within public police organisations. At the conference, the ILO outlined its current conventions for police workers. This was the source of considerable contention. ${ }^{1}$

At the Durban 2002 conference, Southern African police demanded the liberalisation of police labour relations in the region. Conference delegates agreed that workshops should be held with police managers and employees in each Southern African country. These workshops would provide police members with information and skills about social dialogue and collective bargaining in police organisations and initiate discussions with police management about the right to freedom of association. The importance of such arrangements for democracy was asserted strongly. The point made was that democratic freedoms should be extended to all citizens and that public police officers are most likely to respect and safeguard these rights and freedoms if they themselves have access to them.

Since the October 2002 workshop, a series of workshops have been conducted with police members from Southern Africa. The first of these workshops was held in Johannesburg in October 2003. Workshop participants debated ways of improving police labour relations in the Southern African region and provided police members with skills and knowledge about collective bargaining and representation. Representatives of the ILO were invited to assist individual Southern African Development Community country police services to rework their labour relations frameworks and practices. The reworking of these frameworks and practices may take years to come to fruition, but in the meantime police members in Southern Africa are mobilising around the right to freedom of association and to collective bargaining. These rights are viewed by 
participating police members as inextricably linked with the development of democratic policing and with the need to improve the morale and commitment of police members (POPCRU, 2003). Police employee representative organisations are seen as having important roles to play in promoting police reform, in keeping public police organisations' membership in check, and in police redefining notions of citizenship as they engage in their own quest for rights and freedoms within their organisations.

\section{Liberalising Police Labour Rights Globally}

The mobilisation of police employees demanding police labour rights is likely to increase in coming years particularly in democratising countries where democratic rights are being awarded to the general citizenry, often for the first time. As Finnane (2002) argues, the police organisation is both an industry and a workplace and police are as concerned about working conditions and wages as most other employees. Police have strong representative organisations in most liberal democratic countries, either in the form of unions, associations, federations, or lodges. These organisations are often major players in policing organisations and pivotal to internal decision-making processes and in shaping the governance of policing more generally.

In newly emerging democracies (and even in less-than democratic countries), police employees are agitating for increased rights to associate and to collectively bargain. But, how will these emerging organisations be regulated and what shape are they likely to take? Braithwaite and Drahos (2000) point out in their study of the global regulation of business that the nation state remains the actor with the greatest influence in global regulation. In so far as the rights of police members are concerned, governments determine regulatory frameworks. These frameworks are dependent on conceptualisations of policing and security; public sector labour legislation; workplace culture, the extent of state democratisation; existing civil and political liberties; and the degree of emphasis given to governance partnerships. National regulatory frameworks and politics will continue to determine police labour relations particularly given the reluctance of international agencies such as the ILO to intervene with this regulation. This means that in non-democratic countries or emerging democracies, where police organisations are still conceived of as agents of the state, police employees are likely to be denied rights to freedom of association and collective bargaining. This, as we have argued earlier, has the potential to hinder police democratisation projects as well as other reform processes in public police agencies.

If nation states play such a key role in determining police labour and social rights, is the global liberalisation of police labour relations possible? What we have suggested above is that it is, and both regional and international trends will continue to impact on the rights of police workers, particularly in emerging democracies. In the Nordic region, for example, police employees have extensive rights and these rights are rapidly being extended to most European countries. Police unions, particularly from the Netherlands and Sweden, provide support to POPCRU both financially and in terms of programme development. In the Southern African region, the gains made by police workers in South Africa are inspiring police members in bordering countries to reassess 
their police labour-management frameworks and arrangements. POPCRU has been invited to Mauritius and Zambia to advise police managers and associations on possible models for the liberalisation of police labour relations. There are also regional initiatives in the Pacific underway where police members are coming together across national boundaries to share labour-management experiences and to develop nationally appropriate police labour-management frameworks. Australia and New Zealand police labour organisations have been instrumental in assisting countries such as Fiji, the Cook Islands, and Papua New Guinea to develop independent police associations.

Changes in the regulation of police labour rights are likely to develop and diffuse through networks of police unionists. Models of police labour relations frameworks, as is the case with the development of other international forms of regulation, will be 'displayed, symbolically interpreted and copied' (Braithwaite \& Drahos, 2000, p. 580). Modelling is most likely to take place between actors who share similar attributes such as worldviews, political ideologies, and customs. Spatial proximity will facilitate modelling, as we have seen in the case of Europe, Southern Africa, and the Pacific region. International knowledge sharing through workshops, conferences, and informal correspondence is already occurring across national boundaries and across regions. Networks of police unionists and associations are actively sharing their knowledge and experience and advocating changes to international regulation frameworks.

Where does all of this leave international regulatory bodies like the ILO? What regulatory and enforcement capacity does the ILO have in regard to establishing decent work standards and labour rights for police employees? The central role of the ILO is to bring pressure to bear on countries that do not comply with internationally accepted core labour standards. The ILO is a key player in what Braithwaite and Drahos call 'webs of influence' (2000, p. 7) in the sphere of labour-management relations and employee rights and has the most sophisticated consultative machinery for securing compliance of any international organisation (Biffl \& Isaac, 2002). The ILO Conventions play an important role, even in developing countries, in demonstrating best practice benchmarks and providing aspirational norms. In the absence of an international authority like the ILO to enforce specific labour standards, countries are free to pursue their own particular legislation and practices with impunity.

However, the ability of the ILO to positively influence labour-management relations within police organisations is constrained by existing clauses and conventions in regard to the police. By allowing nation states to determine appropriate labour standards for the police, police employees are subject to the political determinations of national governments. The market economy and domestic dynamics have not led to improved police employee rights, particularly in places like Africa and Latin America. Simply depending on the quality of domestic institutions and policies often places workers at a disadvantage with serious consequences for public service delivery. As we have seen in the case of Argentina, these determinations potentially reinforce militaristic characterisations of the police. This in turn limits the capacity of police members to positively contribute to the democratisation of policing with potentially serious consequences for policed communities. 
The ILO periodically revises its conventions. However, this only takes place when member states are receptive to such revisions. In the absence of such revisions, the ILO develops Codes of Practice which are not legally binding. Consequently member states readily support such documents whatever private considerations they may hold about their content. Such Codes of Practice promote social dialogue in the public service. This includes the public emergency services. For example, in January 2003, the ILO held a Joint Meeting on Public Emergency Services in Geneva. The meeting (which included police labour and management representatives) adopted a document entitled 'Guidelines on Social Dialogue in Public Emergency Services in a Changing Environment' in which fundamental labour rights such as freedom of association and the right to bargain collectively are promoted (ILO, 2003b).

A change in the ILO Conventions - unlikely to occur in coming years-would provide a more robust reference point for police labour rights. However, as discussed earlier, even if the ILO were to amend its Conventions, the regulatory capacity of the organisation is limited (Braithwaite \& Drahos, 2000, p. 234). Most countries in the world still fail to comply with the basic conventions on freedom of association and the right to collective bargaining - but the ILO Conventions are used (conveniently) to justify exclusions from certain rights - a target for 'blame diversion,' as we saw in the Argentina case. Added to this, despite recent attempts to strengthen enforcement mechanisms, 'effective enforcement remains a problem where the will and capacity to enforce them is lacking' (Elliot, 2000, p. 7). In reality, the ILO can only resort to dialogue, moral suasion, and technical assistance in enforcing labour standards and conventions. The limited capacity of the ILO to regulate police labour relations will mean that police employees and managers will probably turn to regional groupings and international networks of police representative organisations and advocates of police labour rights in developing fairer labour practices for police.

\section{Conclusion}

For a number of decades there has been a preoccupation in police organisations and in the policing literature about the democratisation of policing. Democratic policing is discussed with reference to accountability structures and processes; civilianisation; policing outcomes and performance measurement; and community participation and partnerships. However, there is no mention of the labour and social rights of police employees in regard to the democratisation of police organisations. This is not surprising given that police are perceived to have acted 'undemocratically' and calls have been made for the police to be 'reigned-in' and made more accountable (Fleming, 2001; Lewis \& Fleming, 2003; Moshe, 2004). We do not disagree with the need for police to be held accountable for their behaviour both in police organisations and in the communities they serve. However, we believe that through extending the labour and social rights of the police and encouraging their social agency, the potential for police accountability and democratisation could be deepened. Through membership of police labour organisations and the activities that go with that, police members are able to directly influence the governance of policing. In so doing, they are able to develop 
skills in problem solving and negotiation, both viewed as imperative to democratic (community) policing. By being part of collective organisations, police members may begin to further appreciate the importance of the right to freedom of association and freedom of expression, both of which are cornerstones of democratic societies.

Equally important to police democratisation projects, the rights of police employees to be part of employee representative organisations and to have a collective voice in work conditions and police practice, bolsters police morale and commitment and facilitates police employee participation in organisational change processes. The existence of (independent) police employee representative organisations and the right to collective bargaining serves to directly challenge the hierarchical and command and control structuring of police organisations. Collective bargaining constrains the ability of police management to make unilateral decisions that aim to protect vested interestsboth in and out of the police organisation. These organisations, therefore, have the potential to transform (even if in small ways) both the cultural knowledge of the police as well as the organisational field of police officers by exposing police to the benefits of social, labour, and human rights. They also inculcate in police officers a sense of agency by demonstrating that they can change their own direct organisational environment.

The potential for such cultural change in police organisations is most clearly evident in the challenges posed to (autocratic) police organisations by POPCRU in South Africa. POPCRU has challenged the hierarchical nature of the South African Police Service, and has provided a watchful eye over police management should they depart from the goals of the organisation's transformation process, in particular the goals of representation, affirmative action, and human rights (Marks, 2000b). Organisations like POPCRU provide police with an agency from which new ways of acting and thinking can be tested. In so doing, these representative collective organisations demonstrate that police officers are powerful agents in changing police culture and practice.

Police employees have become increasingly aware of the benefits of collective representation and bargaining rights. Across the world, police members are demanding the right to associate and to collectively bargain. This is unlikely to change (Finnane, 2002; Griffin, 2001) and police unionisation will most likely proliferate due to diffused knowledge, modelling, and police union networks both regionally and internationally. This can only be regarded as a positive for democratic practice. The ILO, as a key international regulatory body, would do well to take heed of the advantages of these trends and the democratic benefits of the labour rights of police. This may require a review of existing conventions and increased technical support for police who are trying to make a case for their own democratic rights.

\section{Note}

[1] Since the October 2002 workshop the ILO has provided ongoing technical and financial support to the Southern African police labour relations initiative, but has maintained that their interventions are bounded by the existing conventions which seem unlikely to change in the foreseeable future. 


\section{References}

Bayley, D. (1994). Police for the future. New York: Oxford University Press.

Biffl, G., \& Isaac, J. (2002, June 25-29). How effective are the ILO's labour standards under globalisation? Paper presented at the IIRA/CIRA 4th Regional Congress of the America's Centre for Industrial Relations, University of Toronto.

Boda, J. (2003, June 15-17). Transformation-coordination of police in the security sector reform context. Paper presented at the SSR-Track Panel at the 6th Annual Conference of the PFP Consortium for Defence Academies and Security Studies Institutes, Berlin.

Braithwaite, J., \& Drahos, P. (2000). Globalbusiness regulation. Cambridge: Cambridge University Press.

Brogden, M. (1999). Community policing as Cherry Pie. In R. Mawby (Ed.), Policing across the world: Issues for the twenty first century. London: UCL Press.

Brogden, M., \& Shearing, C. (1993). Policing for a new South Africa. London: Routledge.

Chan, J. (1996). Changing police culture. British Journal of Criminology, 36(1), 109-133.

Chan, J. (1997). Changing police culture: Policing in a multicultural society. Melbourne: Cambridge University Press.

Chan, J. (1999). Police culture. In D. Dixon (Ed.), A culture of corruption: Changing an Australian police force. Sydney: Hawkins Press.

Chan, J. (2001). Negotiating the field: New observations on the making of police officers. Australian and New Zealand Journal of Criminology, 34(2), 114-133.

Cox, S. (1996). Police practices, perspectives and problems. Boston: Allyn and Bacon.

Elliot, K. (2000). The ILO and enforcement of core labour standards. International Economics Policy Briefs, 6, 1-7.

Finnane, M. (2002). When police unionise: The politics of law and order in Australia. Sydney: Institute of Criminology, University of Sydney.

Fleming, J. (2001). Conduct unbecoming: Independent commissions and ministerial adversaries. In J. Fleming \& I. Holland (Eds.), Motivating ministers to morality. London: Ashgate.

Gammage, A., \& Sachs, S. (1972). Police unions. Springfield, MA: Charles C. Thomas.

Goldstein, H. (1990). Problem oriented policing. New York: McGraw-Hill.

Griffin, D. (2001, February 27). Police association advocacy-A strategic priority: Police associations, political activism and public opinion. Paper presented at the Police Employment in 2001 Conference, Toronto.

ILO. (2003a, November). ILO governing body on freedom of association: 332nd Report of the Committee on Freedom of Association. Geneva: International Labour Organisation.

ILO. (2003b, January 27-31). Guidelines on social dialogue in public emergency services in a changing environment. Report from a joint meeting on Public Emergency in a Changing Environment, Geneva.

Independent Commission on Policing for Northern Ireland. (1999). A new beginning: Policing in Northern Ireland: The Report of the Independent Commission on Policing for Northern Ireland. Belfast.

Juris, H., \& Feuille, P. (1973). Police unionism. New York: Heath.

Lewis, C., \& Fleming, J. (2003). The everyday politics of value conflict: External independent oversight bodies in Australia. In I. Holland \& J. Fleming (Eds.), Government reformed: Values and new political institution. London: Ashgate.

Marenin, O. (2004). Police training for democracy. Police Practice and Research, 5(2), 107-123.

Marks, M. (2000a). Labour relations in the South African Police Service. In G. Adler (Ed.), Public service labour relations in a democratic South Africa. Johannesburg: University of Witwatersrand Press.

Marks, M. (2000b). Transforming police organisations from within: Police dissident groupings in South Africa. British Journal of Criminology, 40, 557-573.

Marx, G. (2000). The police as social change agents? The curious case of Poland's transition. In M. Los \& A. Zybertowicz (Eds.), Privatising the police state. London: Macmillan. 


\section{M. Marks \& J. Fleming}

Mgijima, B. (2003, January). Best practices in social dialogue in public service emergency services in South Africa. Working paper for the Sectoral Activities Programme, International Labour Organisation, Geneva.

Moshe, M. (2004). Feeling the heat: Anticorruption mechanisms in comparative perspective. Governance: An International Journal of Policy, Administration and Institutions, 17(1), 1-28.

Obeid, E., \& Weisenberg, L. (2003). Case studies in social dialogue in the public emergency servicesArgentina. ILO Sectoral Activities Programme Working Paper No. 193, Geneva.

POPCRU. (2003). Report on the Southern African Development Community Police labour management workshop. Johannesburg: POPCRU Head Office.

Reiner, R. (1978). The blue coated worker: A sociological study of police unionism. London: Cambridge University Press.

Shaw, M. (2002). Crime and policing in post-apartheid South Africa: Transforming under fire. Claremont, South Africa: David Phillip.

Van Zyl Smit, D., \& van der Spuy, E. (2004). Importing criminological ideas in a new democracy: Recent South African experiences. In T. Newburn \& R. Sparks (Eds.), Criminal justice and political cultures: National and international dimensions of crime control. Cullompton, Devon: Willan.

Webster, E. (1988). The rise of social-movement unionism: The two faces of the black trade union movement in South Africa. In P. Frankel, N. Pines, \& M. Swilling (Eds.), State, resistance and change in South Africa. New York: Croom Helm.

Wood, J. (2004). Cultural change in the governance of security. Policing and Society, 14(1), 31-48. 